\title{
Detection of Pseudomonas Syringae pv. Lachrymans Associated with the Seeds of Cucurbits
}

\author{
S. J. Shila, M. R. Islam, N. N. Ahmed, K. M. G. Dastogeer*, M. B. Meah \\ Department of Plant Pathology, Bangladesh Agricultural University, Mymensingh-2202, Bangladesh \\ *Corresponding Author: gdastbau@gmail.com
}

Copyright (C) 2013 Horizon Research Publishing All rights reserved.

\begin{abstract}
Seed-borne bacteria that impair germination and emergence of seedlings and reduce yield and quality of cucurbits are of major concerns for cucurbit production throughout the world. The present investigation has been carried out to detect bacteria from the seeds of eight cucurbits viz. cucumber, bottle gourd, wax gourd, sweet gourd, ridge gourd, bitter gourd, sponge gourd and snake gourd collected from the different shops of Mymensingh town during July to November 2011. Seed samples were tested to detect seed-borne bacteria by nutrient agar plate method, cassette holder and liquid assay method. Only one bacterium was isolated and identified through nutrient agar plate and liquid assay method. The bacterium was identified as Pseudomonas syringae based on creamy white color colonies on the nutrient agar plate. The Pathogenicity test revealed that the bacterium was able to cause leaf spot symptom on the seedlings of all cucurbits confirming that the bacterium was Pseudomonas syringae pv. lachrymans. Hypersensitive response (HR) test on tobacco leaves caused partial death of local cell of tissues (HR) within the infiltrated area of tobacco leaves (cv. Bankete -A1). Gram staining and $\mathrm{KOH}$ test indicated the bacterium was gram negative and it was not able to grow at temperature $37^{\circ} \mathrm{C}$ and above. Positive reactions were observed in levan test, catalase test and sugar utilization test, but soft rot test, arginine dehydrolase and Kovac's oxidase was negative.
\end{abstract}

Keywords Biochemical tests, cucurbit, hypersensitive response, pathogenicity, seed-borne bacteria

\section{Introduction}

Cucurbits are the member of the family cucurbitaceae. Cucurbits are tropically adapted creeper type plants which provide plenty of vegetable in summer especially in rainy season when most of the vegetable crops are out of production. In Bangladesh, cucurbits are most popular and cheap vegetables. They have nutritive status due to presence of carbohydrates, protein, fats, vitamins \& minerals [1]. A commendable area of highland, specially the homestead area during rainy season and crop field in winter are cultivated with cucurbit. This group of vegetable, is either used as salad or for cooking (gourds), for pickling (cucumber), or as desert fruits (musk-melon and water-melon) [2]. In Bangladesh the area denoted for cucumber cultivation is estimated to about 13000 acres with annual production of 230000 metric tons [3]. However, the yield of cucurbit vegetable in the country is very low due to various reasons. One of the major concerns for cucurbit production in Bangladesh is the infestation with seed-borne fungal and bacterial diseases that impairs germination and emergence yield and quality of cucurbits. Cucurbits are subjected to attack by more than 24 different diseases, 14 of them are seed borne-pathogen [4-6]. Cucurbits bacterial leaf spot, bacterial rind necrosis, bacterial soft rot are the most important bacterial disease infecting cucubit plants. Recently, angular leaf spot symptoms caused by a bacterium Pseudomonas syringae pv. lachrymans $[7,8]$ have become apparent on cotyledons, leaves and fruits in Bangladesh, that inflicts up to $37-40 \%$ reduction in fruit production and renders some fruits unmarketable. The disease poses threat not only to cucumber but also to a number of cultivated and wild cucurbits throughout the world. But no systematic study was carried out to identify and characterise the pathogen in Bangladesh. Hence, efforts were made to identify and isolate the harmful pathogen. Therefore, the present investigation deals with the detection and identification of the strain, Pseudomonas syringae pv. Lachrymans from the seeds of eight cucurbits namely cucumber, bottle gourd, wax gourd, sweet gourd, ridge gourd, bitter gourd, sponge gourd, snake gourd.

\section{Materials and Methods}

\subsection{Collection of Seed Sample}

The experiment was conducted in the Seed Pathology Centre (SPC), Bangladesh Agricultural University (BAU), Mymensingh. Seed samples of eight cucurbits, namely sweet gourd, bottle gourd, snake gourd, sponge gourd, wax gourd, bitter gourd, ridge gourd and cucumber, were collected in July 2011 from different shops in Noton Bazar, Mymensingh. 
$200 \mathrm{~g}$ of seed for each cucurbit species was sampled randomly from each. Then the collected seed samples were mixed to make a composite sample for each cucurbit. Then the composite samples were made into small fraction for working sample (around 100 seeds). The samples enclosed in polythene bags with proper labeling were brought directly to Seed Pathology Centre (SPC) and kept in the refrigerator at $4 \pm 1{ }^{\circ} \mathrm{C}$ until used for subsequent studies.

\subsection{Detection of Bacteria}

\subsubsection{Nutrient Agar Plate Method}

External surfaces of Seed samples for each cucurbit species were sterilized with $10 \%$ Clorox for 1 minute. Then the samples were washed with sterile water and the excess water was removed using blotter paper. Five seeds of sweet gourd, bottle gourd, snake gourd, bitter gourd and 10 seeds of sponge gourd, wax gourd, ridge gourd and cucumber were placed on the Nutrient Agar plate. Plates were incubated in an inoculation chamber at $27^{\circ} \mathrm{C}$ for 2 days to allow the growth of bacteria associated with the seeds.

\subsubsection{Cassette Holder Method}

Four seeds for each sample were taken randomly and placed between two layers of filter paper $(4.5 \times 4.5 \mathrm{~cm})$ lined every second silt of the slide cassette holder. The the cassette holder with the filter paper was put in a tray filled with 230 ppm urea solution until it covered cover $2 \mathrm{~cm}$ of the cassette. Symptoms of brown coleoptile, water soaked and yellow discolorations of leaves were also observed.

\subsection{Liquid Assay Method}

To identify seed borne bacteria associated with seeds of different cucurbits species, liquid assay method as described by Moura and Romeiro [9] was used. Five to ten seeds from each sample were grinded by mortar and pestle into powdery masses. The seed powder was mixed in $50 \mathrm{ml}$ sterile water and incubated for $2 \mathrm{hrs}$ at room temperature with periodical shaking. $1 \mathrm{ml}$. of the suspension was added in $9 \mathrm{ml}$ of sterile water to make $10^{-1}$ dilution. Then $1 \mathrm{ml}$. aliquot from first dilution $\left(10^{-1}\right.$ dilution) was added in $9 \mathrm{ml}$. sterile water to prepare second dilution ( $10^{-2}$ dilution). Similarly, $10^{-3}$ and $10^{-4}$ dilutions were made by taking $1 \mathrm{ml}$. aliquot from previous dilution and mixing with $9 \mathrm{ml}$.sterile water in each case. A L- shaped glass spreader was used to smear the suspension on nutrient agar plate that was incubated in an incubator at $27^{\circ} \mathrm{C}$ for 2 days. Single colonies were transferred another nutrient agar plates for purification. From the pure colony of bacteria on NA media bacterial slant was then prepared in NA slant for future identification.

\subsection{Pathogenicity Test}

Pathogenicity test was performed using one month old cucurbits viz. cucumber, bottle gourd, wax gourd, sweet gourd, ribbed gourd, bitter gourd, sponge gourd and snake gourd seedlings as described by Lelliot and Stead [10]. Bacterial suspension (approximately $10^{6}-10^{7}$ cells $/ \mathrm{ml}$ ) was prepared from the $24 \mathrm{hrs}$ old culture of different isolates of Pseudomonas sp. The suspension was sprayed onto the leaves of cucurbit seedlings in 3-4 true leaf stage grown in pots by hand sprayer. Inoculated cucurbit seedlings were covered with a black polythene sheet to create $80-90 \%$ relative humidity for $48 \mathrm{hrs}$. Then black polythene sheets was replaced by a transparent polythene sheet to conserve moist condition. Then the seedlings were kept on the net house. The symptoms were noted up to 10 days. During the experiments plants were watered regularly and wetted with hand sprayer. Check plants were sprayed with distilled water.

\subsection{Tobacco Hypersensitive Response (HR) Test}

At 30-40 days old tobacco plants, bacterial suspension (approximately $10^{6} \mathrm{CFU} / \mathrm{ml}$ ) of isolate representing a group was injected in the leaves. Bacterial suspensions were injected into the intracellular space of the leaf with a hypodermal syringe. Hypersensitive reaction was observed daily and continued up to five days of infiltration. Necrotic lesion on the leaves were recorded positive [2].

Soft rot test: Well washed, firm potatoes were surface sterilized, peeled aseptically and three standard slices were peeled in sterile petridishes, the bottom of which was lined with moist filter paper (What man no. 1). Two slices were then inoculated with loopful of bacteria previously grown on Nutrient Agar culture of each isolate and incubated at room temperature for 24-48 hrs for the detection of soft rot symptoms. A control for each isolate was maintained using loopful of sterile water. Pectolytic activity was performed to observe the condition of the sliced potato [10].

Temperature sensitivity test: The ability of bacterial isolates to grow at different selected temperature at $27^{\circ} \mathrm{C}$, $37^{\circ} \mathrm{C}$ and $41^{\circ} \mathrm{C}$ were tested by initially growing isolate on NA for $24 \mathrm{hrs}$. The bacterial suspension of isolate was prepared from $24 \mathrm{hrs}$ NA culture to $5 \mathrm{ml}$ of nutrient broth. 2-3 drops of bacterial suspension was taken in nutrient broth contained in test tubes which were placed at temperature $27^{\circ} \mathrm{C}, 37^{\circ} \mathrm{C}$ and $41^{\circ} \mathrm{C}$.

\subsection{Biochemical Tests for Identification of Pseudomonas Syringae Pv. Lachrymans}

Pseudomonas syringae pv. lachrymans detected in the seeds of eight cucurbits was characterized by several biochemical tests viz. Gram staining, Potassium hydroxide solubility,Kovac's, Levan, Sugar fermentation, Catalase and Arginine dihydrolase test

Gram staining reaction: $24 \mathrm{hrs}$ old fresh bacterial cultures for each group of isolates were taken to perform the gram reaction test. Bacterial mass were taken out from culture, spread on clean glass slide followed by drying in air without heat and was flamed it lightly and gently to settle the bacteria. Crystal violet was then poured over the bacterial 
smear on the slide for 2-3 minutes and washed in tap water for 1 minute and lightly blot dry on a paper towel to remove crystal violet. The smear was flooded with iodine solution for 1 minute and washed in tap water for few seconds and then blot dried. It was decolorized with solvent e.g. alcohol, until the solvent flowed colorlessly from the slide (about 2-4 seconds) and rinse in tap water for 5 seconds. Then the smear was counterstained for about 1 minute with safranin solution and washed briefly in tap water followed by blot dry. One drop emulsion oil was then added on the slide and placed it on compound microscope with $100 \mathrm{x}$ magnification for observation.

Potassium hydroxide solubility test: On glass slide a loopful of bacteria from a well grown colony was mixed with $1-2$ drop of $3 \% \mathrm{KOH}$ solution was placed on microscope slides, bacterial isolates was slowly stirred in the $\mathrm{KOH}$ solution by means of a loopfull and the loopfull was slowly raised from the solution. If the solution was mucoid and it was streched as fibres it was recorded as positive. If the solution was watery,not mucoid and fibres formation was not occured while the loofull was raised it was recorded as negative [12].

Kovac's oxidase test: A filter paper was placed into a clean peridish and impregnated with $1 \%$ aqueous solution of Nitrogen, (Nitrogen tetramethyl-p-phenolin-diamine dihydrochloride). Then, a loopful inoculum from pure culture was picked up by sterilized platinum loop. The inoculum was smeared over the area of filter paper containing oxidize reagent to develop deep blue or purple color within ten seconds indicating the oxidation of the reagent [13].

Levan test: Bacteria that have the enzyme levan sucrase, can break down sucrose and produced levan (Poly-fructose), a capsular material. Sucrose peptone agar or a nutrient agar medium with 5\% sucrose is suitable substrate for Levan test. For the test a single colony for each isolate was stabbed with a sterilized tooth pick on NA medium containing 5\% sucrose. Then the plates were incubated at $28^{\circ} \mathrm{C}$ for 2 to 4 days to have distinctive dome shaped colonies.

Sugar Utilization test: The medium consists of peptone water to which fermentable sugar was added in the proportion of $1 \%$. Peptone water was prepared by adding $1 \mathrm{~g}$ of Bacto peptone (Difco, USA) and $0.5 \mathrm{~g}$ of sodium chloride in $100 \mathrm{ml}$ distilled water. The medium was boiled for 5 minutes, adjusted to $\mathrm{pH}$ at 7.0 , cooled and then filtered through filter paper. Phenol red, an indicator at the strength of $0.2 \%$ solution was added to peptone water and then dispensed $5 \mathrm{ml}$ in Durham's fermentation tubes, placed inversely. These were then sterilized in autoclave at $121^{\circ} \mathrm{C}$ maintaining at 15 PSI pressure for 15 minutes. The sugars used for fermentation test were prepared separately as $10 \%$ solution in distilled water (10 g sugar was dissolved in 100 $\mathrm{ml}$ of distilled water). A little heat was given to dissolve the sugar completely. The sugar solutions were sterilized using filters. An amount of $0.5 \mathrm{ml}$ of sterile sugar solution was added aseptically in each culture tubes containing sterile peptone water and the indicator. Before use, the sugar media was sterilized and incubated it for 24 hours at $37^{\circ} \mathrm{C}$. The carbohydrate fermentation test was performed by inoculating a loop full of nutrient broth culture of the organisms into the tubes containing different sugar media (four basic sugars such as dextrose, sucrose, lactose, and manitol) and incubated for 24 hours at $37^{\circ} \mathrm{C}$. Acid production was indicated by the color change from reddish to yellow in the medium and the gas production was noted by the appearance of gas bubbles in the inverted Durham's tubes.

Arginine dihydrolase activity: The test was performed to observe the presence of two enzymes that permits certain Pseudomonads to grow under anerobic conditions. The enzymes generate ATP by the degradation of arginine to ornithine with the generation of $\mathrm{Co}_{2}$ and $\mathrm{NH}_{3}$. The two enzymes are arginine desmidase which degrades arginine to citrulline $+\mathrm{Co}_{2}+\mathrm{NH}_{3}$. It is the alkaline reaction of $\mathrm{NH}_{3}$ production that is detected by the test. To prepare the medium $0.2 \mathrm{~g}$ peptone, $1 \mathrm{~g} \mathrm{NaCl}, 0.06 \mathrm{~g} \mathrm{~K}_{2} \mathrm{HPO}_{4}, 0.6 \mathrm{~g}$ Agar, $0.02 \mathrm{mg}$ Phenol red and $2 \mathrm{~g}$ Arginine $\mathrm{HCl}$ was taken in a conical flask and mixed with $200 \mathrm{~mL}$ water. The conical flask was shaken gently for mixing the chemicals properly. The $\mathrm{pH}$ was adjusted at 7.2. These were then sterilized in autoclave at $121^{\circ} \mathrm{C}$ maintaining at 15 PSI pressure for 15 minutes. A fresh culture was stabbed into a soft agar tube of Thornley's medium, sealed with sterile mineral oil or melted agar and incubated at $28^{0} \mathrm{C}$. A color change from faint pink to red within four days is positive reaction [14].

Catalase Test: This test was performed to isolates to check their liveliness. Standard cultures are used for control purpose. One milliliter of 3\% hydrogen peroxide was placed on the microscope slides. The bacterial isolates collected from the leaf samples were tested for catalase test. Bacterial isolates developed in NA medium for $24 \mathrm{hrs}$ were added by a loopful. Bubbles' arising from the solution was recorded as positive reaction. This test is used to detect the enzyme catalase. This enzyme is responsible for protecting bacteria from hydrogen peroxide $\left(\mathrm{H}_{2} \mathrm{O}_{2}\right)$ accumulation, which can occur during aerobic metabolism. Catalase breaks $\mathrm{H}_{2} \mathrm{O}_{2}$ down into water and $\mathrm{O}_{2}$.

\section{Results and Discussion}

\subsection{Detection of Pseudomonas syringae pv. lachrymans on cucurbit seeds}

Both Nutrient Agar Plate and Liquid assay method revealed the presence of only one bacterium in all the seeds of cucurbits. Creamy white color colonies grown on NA plate from different cucurbit seeds as tested by both nutrient agar plate and Liquid assay method primarily indicated that the bacterium was Pseudomonas (It's a repletion). Smith [15] reported that Pseudomonas lachrymans, isolated from cucumber or muskmelon, formed white, slightly raised, transparent, smooth surfaced and circular colonies with irregular edges on beef-extract agar producing abundant green fluorescent pigment but the colonies were slightly 
raised, filiform, white and butyrous on potato dextrose agar. Palleroni [16] reported that King's medium B is frequently used for direct isolation of fluorescent pseudomonads and their colonies can be identified on the plates by characteristic diffusible pigments. Saprophytic pseudomonads are reported to produce more fluorescent pigment on King's medium B than the pathovars of Pseudomonas syringae, which fluoresce blue by visualizing the colonies under UV light [17]. Pseudomonas syringae pv. lachrymans and other pathovars of this species are reported to form levan type colonies on nutrient sucrose agar within three days, which constitutes as a distinguishing character of the species [8].

\subsection{Potato Soft Rot Test}

Potato soft rotting test was performed using the bacterium obtained from different samples of cucurbit seeds did not able to cause soft rot symptoms in potato (Table. 1). Hence the bacterium might be Pseudomonas syringae. The temperature sensitivity test reveled that none of the isolates can grow at $37^{\circ} \mathrm{C}$ and $41^{\circ} \mathrm{C}$ and but can grow at $27^{\circ} \mathrm{C}$ (Table. 1). Schaad et al [18] also reported that Pseudomonas syringae pv. lachrymans has no ability to degrade the pectolytic substance of potato while the test was observed positive in case of Pseudomonas viridiflava, $P$. marginalis and E. carotovora subsp. carotovora.. Ohuchi et al. [19] studied biochemical characters of 110 Japanese isolates of $P$. syringae $p v$. lachrymans pathogenic to cucumber, and found that all of these were negative for potato soft rot activity.

\subsection{Pathogenicity and Hypersensitive Response Test}

All isolates produced typical symptoms of angular leaf spot/leaf blotch symptoms in seedlings of eight cucurbits tested, 15 days after inoculation, causing greasy and individual spots (Fig.1 and Table 2). The first symptoms appeared three days after inoculation and no differences in pathogenicity were found between other isolates. Therefore, it may be confirmed that the bacterium detected in the seeds of cucurbits was $P$. syringae pv. lachrymans. This result is an agreement with the findings of Aksoy [20]who confirmed $P$. syringae $\mathrm{pv}$. lachrymans as the causal organism of bacterial leaf spot of cucurbits by pathogenicity test. $P$. syringae pv. lachrymans detected from all cucurbit seeds were tested for hypersensitive reaction in tobacco. Results of this test showed that the isolates were able to cause partial death of local cell of tissues (HR) within the infiltrated area of tobacco (cv. Banket-A1) leaves (Fig. 2). Gvozdyak et al. [21] also showed the hypersensitive reaction on the tobacco leaf and the hypersensitive reaction was most distinctly manifested when 1-3 days old bacterial cultures of $P$. syringae pv. lachrymans were used. Several other findings such as those reported by Misaghi and Grogan [22] and Bradbury [8] also pointed out that $P$. syringae $p v$. lachrymans pathogenic to cucurbits and showed positive reaction with respect to hypersensitivity to tobacco.

Table 1. Morphological and Physiological Characteristics of Pseudomonas syringae pv. Lachrymans

\begin{tabular}{|c|c|c|c|c|c|c|}
\hline \multirow{2}{*}{$\begin{array}{c}\text { Name of the seed } \\
\text { sample }\end{array}$} & \multirow{2}{*}{$\begin{array}{l}\text { Colony morphology on } \\
\text { nutrient agar plate }\end{array}$} & \multirow{2}{*}{$\begin{array}{l}\text { Potato soft rot } \\
\text { test }\end{array}$} & \multicolumn{3}{|c|}{ Temperature sensitivity test } & \multirow[b]{2}{*}{ Inference } \\
\hline & & & $27^{\circ} \mathrm{C}$ & $37^{\circ} \mathrm{C}$ & $41^{\circ} \mathrm{C}$ & \\
\hline Sweet gourd & Creamy White & - & + & - & - & $\begin{array}{c}\text { Pseudomonas } \\
\text { syringae } \mathrm{pv} . \\
\text { lachrymans }\end{array}$ \\
\hline Wax gourd & Creamy White & - & + & - & - & $\begin{array}{c}\text { P. syringae pv. } \\
\text { lachrymans }\end{array}$ \\
\hline Bottle gourd & Creamy White & - & + & - & - & $\begin{array}{l}\text { P. syringae pv. } \\
\text { lachrymans }\end{array}$ \\
\hline Bitter gourd & Creamy White & - & + & - & - & $\begin{array}{l}\text { P. syringae pv. } \\
\text { lachrymans }\end{array}$ \\
\hline Snake gourd & Creamy White & - & + & - & - & $\begin{array}{l}\text { P. syringae } \mathrm{pv} \text {. } \\
\text { lachrymans }\end{array}$ \\
\hline Sponge gourd & Creamy White & - & + & - & - & $\begin{array}{l}\text { P. syringae pv. } \\
\text { lachrymans }\end{array}$ \\
\hline Ridge gourd & Creamy White & - & + & - & - & $\begin{array}{l}\text { P. syringae pv. } \\
\text { lachrymans }\end{array}$ \\
\hline Cucumber & Creamy White & - & + & - & - & $\begin{array}{c}\text { P. syringae } \mathrm{pv} . \\
\text { lachrymans }\end{array}$ \\
\hline
\end{tabular}

“+” = Positive Reaction and “-” = Negative Reaction 


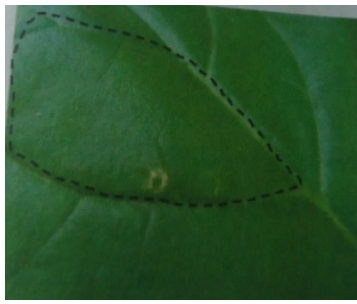

A

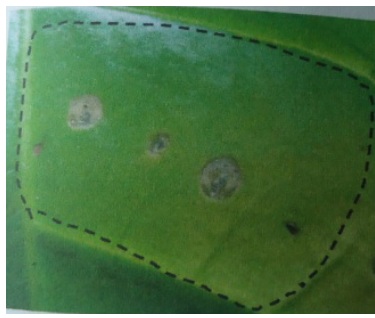

$\mathrm{F}$

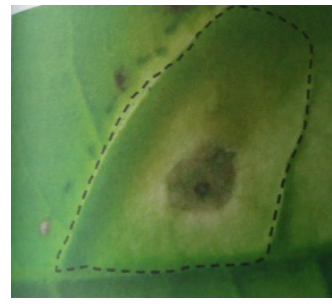

B

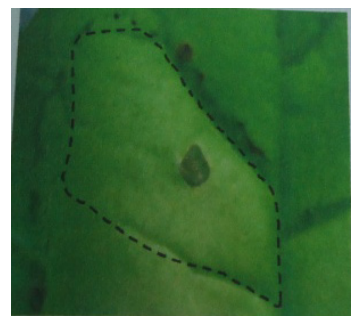

G

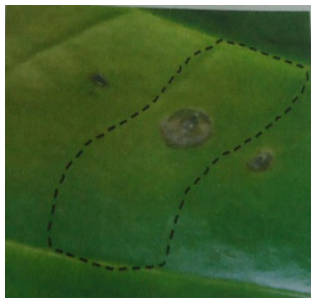

C

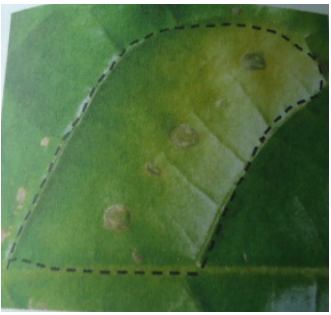

$\mathrm{H}$

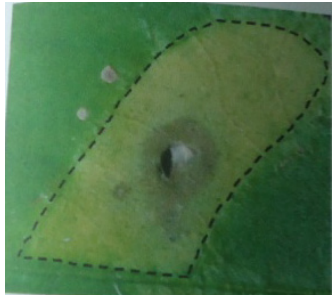

D

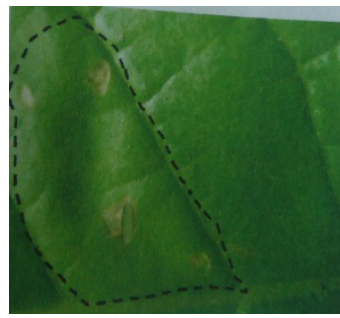

Figure 1. Hypersensitive response test on tobacco leaves infiltrated with isolates of $P$. syringae pv. lachrymans seeds of B. Cucumber, C. Bottle gourd, D. Sweet gourd, E. Ridge gourd, F. Ash gourd, G. Snake gourd, H. Bitter gourd, I. Sponge gourd. Areas inside the dotted line infiltrated with bacterial suspension (B-I) and control (A)

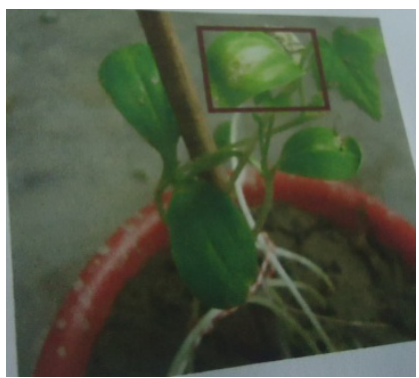

A

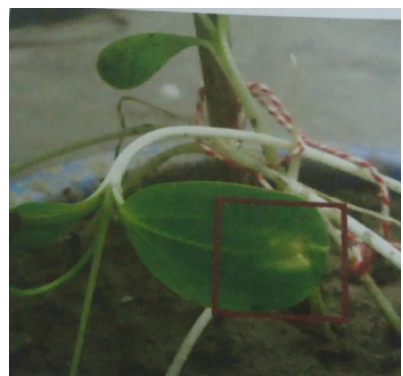

E

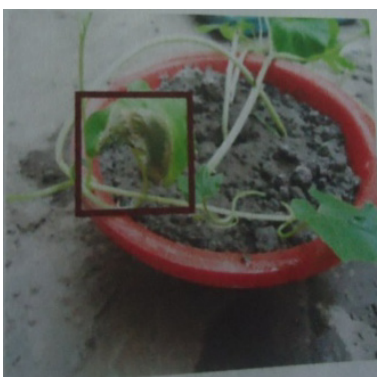

B

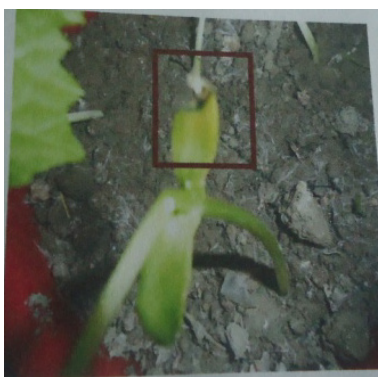

$\mathrm{F}$

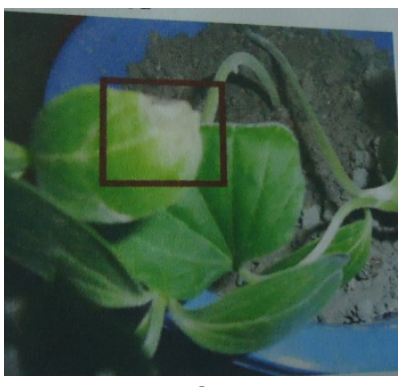

C

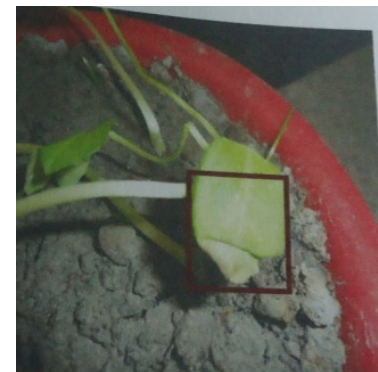

G

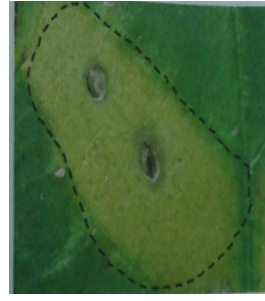

$\mathrm{E}$

Figure 2. Pathogenecity test of P. syringae pv. lachrymans isolated from seeds of A. Cucumber, B. Bottle gourd, C. Sweet gourd, D. Ridge gourd, E. Ash gourd, F. Snake gourd, G. Bitter gourd, H. Sponge gourd (Red box shows lesion on leaves)

\subsection{Biochemical Tests}

Biochemical tests viz. gram staining test, $\mathrm{KOH}$ test, levan test, catalase test, oxidase test were performed to characterize the isolates of Pseudomonas syringae pv. lachrymans detected in the seeds of eight cucurbits. $\mathrm{KOH}$ solubility test and gram staining reaction showed the bacterium was gram negative (Table. 2). With respect to the Kovac's oxidase test Pseudomonas syringae pv. lachrymans did not give the positive reaction revealing that it has no oxidizing ability. The isolates of Pseudomonas syringae pv. lachrymans detected in the seeds of eight cucurbits were confirmed by levan test and sugar utilization test. The isolates were able to produce round or circular dommed shaped colonies in sucrose medium. The acid production in sugar fermentation test by the bacteria were indicated by the color change from reddish to yellow; gas production was noted by the appearance of gas bubbles in the inverted Dhuram's tubes and the oxidation of sugar manitol by isolates indicated by the production of red to yellow color. All the bacterial isolate were also subjected to test with arginine dihydrolase test. Results of this test showed that the isolates were able to raise the $\mathrm{pH}$ and change the color of the medium from faint pink to red. This results clearly indicated that the bacterium was Pseudomonas syringae pv. lachrymans. Again, catalase test for Pseudomonas syringae pv. lachrymans isolates detected in the seeds of cucurbits showed positive reaction by the appearance of arising bubbles (Table. 2). 
Suslow et al. [23] reported that the $\mathrm{KOH}$ technique is far easier and faster to distinguish gram negative and gram positive bacteria than the traditional Gram-strain in which dyes are employed. Smith [15] studied the morphological characters of Pseudomonas lachrymans and reported that the bacterium was Gram-negative, rod shaped with rounded ends, nonacid fast, motile with one to three polar flagella. Kagiwata [24] studied the morphological characters of several isolates of $P$. syringae $p v$. lachrymans isolated from all over Japan and reported that all were Gram negative, aerobic, non-sporing, straight rods and motile with one to five polar flagella. Bradbury [8] in his detailed account of genus Pseudomonas, its species and pathovars reported that pseudomonads are Gram-negative, aerobic rods, straight or curved and range 0.5-1.0 $\times 1.5-4.0 \mu \mathrm{m}$ in size. Smith [15] reported that $P$. lachrymans was negative for nitrate reduction, production of indole and hydrogen sulphide, and starch hydrolysis but was positive for ammonia production. He further reported that the bacterium utilized arabinose, xylose, sucrose, dextrose, levulose, galactose, mannose and sorbitol but not rhamnose, maltose, lactose, trehalose, raffinose, melizitose, melibiose, cellobiose, starch, inulin, dextrin, glycogen, inositol, glycerol, dulcitol, erythritol, salicin, esculin and arbutin.

Our result is in line with the findings of Aksoy [20] who reported that the isolates of Pseudomonas syringae $p v$. lachrymans were able to produce round or circular dommed shaped colonies in sucrose medium. Lelliot et al. [25] reported that $P$. Lachrymans as positive for Levan production, tobacco hypersensitivity and sucrose utilization but negative for oxidase, potato rot, arginine dihydrolase and nitrate reduction with different isolates giving varied results in case of tyrosinase activity and aesculin utilization. Our present result is in accoddance with the findings of Aksoy [20] who reported that Pseudomonas syringae $p v$. lachrymans shows negative reaction in arginine dihydrolase and Catalase test as gram negative bacteria. A negative reaction in arginine dihydrolase test was also reported by Schadd et al [18]. Misaghi and Grogan [22] reported that $P$. lachrymans isolates were negative for oxidase, potato rot, and arginine hydrolase tests. Ohuchi et al. [19] studied biochemical characters of 110 Japanese isolates of $P$. syringae $p v$. lachrymans pathogenic to cucumber, and found that all of these were positive, production of Levan, liquefaction of gelatin, utilization of tartarate and sucrose, but were negative for growth at $37^{\circ} \mathrm{C}$, arginine dihydrolase, oxidase, tryrosinase, casein hydrolysis, cotton oil hydrolysis, nitrate reduction and potato soft rot activity. Bradbury [8] summarized the biochemical description of $P$. syringae $p v$. lachrymans as positive for levan production from sucrose and tobacco hypersensitivity and negative for arginine dihydrolase, oxidase, starch hydrolysis and potato rot. Scortichini et al. [26] reported that the capability of aesculin utilization by P. syringae pv. lachrymans disappeared after serial transfers on King's B medium as well as after the passage through non-host plants and as such suggested that carbohydrate utilization ability of the bacterium would vary according to the different environments in which it had lived. Variation due to frequent subculturing of P. syringae pv. lachrymans in utilization of glycerol, ribose, D-xylose, rhaminose, inositol, and mannitol has also been reported [26]. In a comperative study of phytopathogenic pseudomonads, Braun-Kiewnick and Sands [17] reported that $P$. syringae pv. lachrymans was positive for pectate lyase, beta-glucosidase, polygalacturonase, aesculin hydrolysis, arbutin hydrolysis, gelatin liquefaction, levan production and ice nucleation, and could utilize D-mannitol, insitol, D-sorbitol, trigonalline, D-quinate, erythritol, $\mathrm{L}(+)$ tartarate, glutarate and DLglycerate but not adonitol, D(-) tartarate, L-lactate, anthranilate and DL-homoserine for growth.

The findings of the present study give an indication of the presence of a bacterium in cucurbit seeds. The bacterium isolated and and identified as P.syringae pv. syringae is a pathogenic bacterium. Therefore, cucurbit seeds available in the markets should be subject to health test for bacteruim before sowing. Further studies need to be undertaken in order to get the detailed information pertaining to the identity and mode of function of the bacterium with a view to developing pathogen targeted and sustainable management approaches. 
Table 2. Pathogenecity and Biochemical tests of Pseudomonas syringae pv. Lachrymans

\begin{tabular}{|c|c|c|c|c|c|c|c|c|c|c|c|c|c|}
\hline \multirow{2}{*}{$\begin{array}{c}\text { Name of } \\
\text { the seed } \\
\text { sample }\end{array}$} & \multirow{2}{*}{$\begin{array}{l}\text { Patho } \\
\text { geneci } \\
\text { ty } \\
\text { test }\end{array}$} & \multirow{2}{*}{$\begin{array}{c}\text { Tobacco } \\
\text { Hypersensitivi } \\
\text { ty reaction }\end{array}$} & \multirow{2}{*}{$\begin{array}{l}\text { Gram staining } \\
\text { reaction }\end{array}$} & \multirow{2}{*}{$\begin{array}{l}\mathrm{KOH} \text { solubility } \\
\text { test }\end{array}$} & \multirow{2}{*}{$\begin{array}{c}\text { Kovac's } \\
\text { oxidase } \\
\text { test }\end{array}$} & \multirow{2}{*}{ Levan test } & \multicolumn{4}{|c|}{ Sugar fermenttion test } & \multirow{2}{*}{$\begin{array}{c}\text { Arginine } \\
\text { dehyrolyse } \\
\text { Test }\end{array}$} & \multirow{2}{*}{$\begin{array}{c}\text { Catalase } \\
\text { test }\end{array}$} & \multirow{2}{*}{ Inference } \\
\hline & & & & & & & Dextrose & Sucrose & Manitol & Lactose & & & \\
\hline $\begin{array}{l}\text { Sweet } \\
\text { gourd }\end{array}$ & + & + & Gram negative & Gram negative & - & + & + & + & + & + & - & + & P. syringae pv. lachrymans \\
\hline Wax gourd & + & + & Gram negative & Gram negative & - & + & + & + & + & + & - & + & P. syringae pv. lachrymans \\
\hline $\begin{array}{l}\text { Bottle } \\
\text { gourd }\end{array}$ & + & + & Gram negative & Gram negative & - & + & + & + & + & + & - & + & P. syringae pv. lachrymans \\
\hline Bitter gourd & + & + & Gram negative & Gram negative & - & + & + & + & + & + & - & + & P. syringae pv. lachrymans \\
\hline $\begin{array}{l}\text { Snake } \\
\text { gourd }\end{array}$ & + & + & Gram negative & Gram negative & - & + & + & + & + & + & - & + & P. syringae pv. lachrymans \\
\hline $\begin{array}{l}\text { Sponge } \\
\text { gourd }\end{array}$ & + & + & Gram negative & Gram negative & - & + & + & + & + & + & - & + & P. syringae pv. lachrymans \\
\hline $\begin{array}{l}\text { Ridge } \\
\text { gourd }\end{array}$ & + & + & Gram negative & Gram negative & - & + & + & + & + & + & - & + & P. syringae pv. lachrymans \\
\hline Cucumber & + & + & Gram negative & Gram negative & . & + & + & + & + & + & . & + & P. syringae pv. lachrymans \\
\hline
\end{tabular}

“+” = Positive Reaction, “-” = Negative Reaction 


\section{REFERENCES}

[1] T. K. Bose and M.G. Som. Vegetable Crops in India, Published by B Mitra, Naya Prokash, 206 Bidhan Sarani, Calcutta. India, 94-95, 1986

[2] T. K. Bose, J. Kabir, T. K. Maity, V. A. Parthasarathy and M. G. Som. Vegetable Crops, New Sarada Press, 9c, Sibnarayan Das Lane, Calcutta 700006, Vol. 1, P. 493, 2002.

[3] BBS (Bangladesh Bureau of Statistics). Yearbook of Agricultural Statistics of Bangladesh. Bangladesh Bureau of Statistics Division, Ministry of Planning, Govt. of the Peoples Repub. Bangladesh, Dhaka, p. 45, 2010.

[4] M. J. Richardson. An annonated list of seed- borne disease. Int. Seed Test Assoc Wageningen. The Netherlands, 3rd Edt. pp. $65-68.1973$.

[5] W. T. H Peregrine, K. B. Ahmad and M. Momin. Controlling anthracnose in Water melon. World crops, Vol. 36, No. 5, 184 $-185,1984$.

[6] W. T. H. Peregrine and K. B. Ahmad. Chemical and Cultural control of anthracnose in water melon. Tropical Pest Manage ment, Vol. 29, No. 1, 42- 46, 1983.

[7] J.M. Young, D. W. Dye, J. F. Bradbury, C. G. Panagopoulos and C. F. Robbs A proposed nomenclature and classification for plant pathogenic bacteria. New Zealand Journal of Agricultural Research, 21, 153-177, 1978.

[8] J. F. Bradbury. Guide to Plant Pathogenic Bacteria. CAB International Mycological Institute, p. 329. 1986.

[9] Moura and Romeiro. Inoculation of cucumber seeds and detection of Pseudomonas syringae pv. lachrymans by biological baits, Revista-Brasileira de Sementes. Vol. 19, No. 2, 380-383, 1997

[10] R. A. Lelliot, and D. E. Stead. Methods for the diagnosis of bacterial diseases of plants, Methods in Plant pathology. Vol. 2. Ed. T.F. preece. Blackwell Sci. Pub.P. 216, 1987.

[11] Z. Klement, A. Mavridis, K. Rudolph, A. Vidaver, M. C. M. Perombelon and L. W. Moore, Inoculation of Plant Tissue. In: Methods in phytobacteriology, Akademia Kiado Budapest, pp: 95-124, 1990.

[12] P. C. Fahy and G. C. Parsley,. Plant Bacterial Diseases: A Diagnostic Guide, Academic Press. London, pp 110-111, 1983.

[13] Kovacs, N., 1956. Identification of Psedudomonas pyocyanae by oxidase reaction. Nature, 170-703.

[14] M. J. Thornley. The Differentiation of Pseudomonas from

other gram negative bacteria on the basis of arginin metabolism, J. Aapplied Bacteriology, 1: 3-52, 1960.

[15] M. A. Smith. Bacterial spot of honeydew melon, Phytopathology, 36: 943-949, 1946

[16] N. J. Palleroni. Genus I Pseudomonas Mingula 1894 pp. 141-199. In: Bergey's Manual of Systematic Bacteriology, Vol. I (Eds. N. R. Krieg and J. G. Holt). Williams and Wilkins, Baltimore, 1984.

[17] A. Braun-Kiewnick and D. C. Sands. Pseudomonas, pp. 84-120. In: Laboratory guide for dentification of plant pathogenic bacteria, third edition (Eds. N. W. Schaad, J. B. Jones and W. Chun). The American Phytopathological Society, Minnesota, USA, 2001

[18] N.W. Schaad, J.B. Jones and W. Chun. Laboratory Guide for Identification of Plant Pathogenic Bacteria, The American Phytopathological Society, 3rd Edt. Pp. 84-103, 2001

[19] A. Ohichi, Y. Shimazaki and A. Ezuka. A rapid method for detecting pseudomonas lachrymans by ooze exudation of inoculated cucumber fruit. Buttetin of the national institute of Agricultural Sciences, C. 34, 29-49. 1980

[20] H. M. Aksoy. Occurrence of Pseudomonas syringae pv. lachrymans at Bafra province Greenhouses. Plant Pathology Journal. Vol. 5, No.1, 80-82, 2006.

[21] Gvozdyak, Pasichnyk, Khodos and Vashchenko. Effect of physiological state of bacteria and heavy metals on hypersensitive reaction on the tobacco leaf. Mikrobiologichnii Zhurnal. Vol. 63, No. 6, 25-31, 2001.

[22] I. Misaghi and R. G. Grogan. Nutritional and biochemical comparisons of plant-pathogenic and saprophytic fluorescent psesdomonads. Phytopathology, 59, 1436-1450, 1969.

[23] T. V. Suslow, M. N. Schroth and M. H. Isaka. Application of rapid method for gram differentiation of plant pathogenic and saprophytic bacteria without staining phytopathology. 72, 917-918, 1982.

[24] T. Kagiwata. Bacteriological characteristics of cucumber angular leaf spot pathogen Pseudomonas syringae pv lachrymans, Journal of Agricultural Science, 35, 116-128, 1990.

[25] R. A. Lelliot, E. Billing and A. C. Hayward. A determinative scheme for the fluorescent plant pathogenic pseudomonads, Journal of Applied Bacteriology, 29, 470- 489, 1966

[26] M. Scortichini, F. G. Tropiano and M. P. Rossi. Variability of whole-cell protein profile, carbohydrate utilization and virulence of one isolate Pseudomonas syringae pv. lachrymans during successive passages through host and non-host plants and serial transfers of a bacterial culture medium. Petria 5, 119-135, 1995. 